\title{
The Legal STATUS OF AN ADVOCATE'S ARTICLED CLERK in the Polish Civil Court Proceedings - REMARKS ON COMPARATIVE BACKGROUND
}

\section{Introduction}

Legal entities may take legal action either alone or with the assistance of other persons. The substantial scope of the concept of legal representation, in its broad sense, covers all forms of involvement of other entities in the procedure of undertaking legally significant activities. In turn, the narrow representation, also referred to as advocacy, includes the action of the representative on behalf of the represented person. ${ }^{1}$ Power of attorney is a special type of representation, which basically boils down to a declaration of will to empower other person to act exclusively on behalf of someone else. The institution of legal representation is regulated in the Polish Code of Civil Procedure. ${ }^{2}$ Only Article 92 of the Code of Civil Procedure contains a reference to the provisions of the Civil Code, ${ }^{3}$ regarding the scope, duration and effects of the authorization broader than a power of attorney, as well as the authorization for individual procedural

* Dr., The John Paul II Catholic University of Lublin; e-mail: kinga.drozdz-chmiel@kul.pl, https://orcid.org/0000-0001-7554-5601.

1 K. Wiszniewski, in: I. Wiszniewska, K. Wiszniewski, Petnomocnictwo procesowe w sprawach cywilnych. Komentarz praktyczny z orzecznictwem, Warszawa 2014, p. 3. For the origin and history of the legal representation, cf. M. Kaczyński, Petnomocnik z urzędu w sadowym postępowaniu cywilnym, Warszawa 2014, pp. 1-6.

2 Act of 17 November 1964 - Code of Civil Procedure, (consolidated text: Journal of Laws of 2019, item 1460, as amended); hereinafter referred to as K.p.c.

3 Act of 23 April 1964 - Civil Code, (consolidated text: Journal of Laws of 2019, item 1145). 
activities. When referring to the regulations of the Code of Civil Procedure [K.p.c.], one should note that the admissibility of action by a proxy results from Article 86 of the Code of Civil Procedure, according to which the parties and their organs or legal representatives may act before a court in person or through their proxies. The institution of legal representation itself is regulated in art. 86-97 K.p.c. ${ }^{4}$ And in Article 87 § 1-6 K.p.c., Article $465 \S 1$ i $\S 1^{1}$ K.p.c., Article $479^{29} \S 3$ K.p.c., Article $479^{51}$ K.p.c., Article $479^{62}$ K.p.c. \& Article $479^{73}$ K.p.c. define the specific group of subjects that can perform the functions reserved for legal representatives. This separate group of subjects participating in a civil case are articled clerks in the professions of advocate, legal adviser and patent agent, who replace, respectively - advocates, legal advisers or patent agents, acting in specific proceedings, on the basis of documents issued to them and called powers of attorney or proxies.

\section{Legal basis for the participation of articled clerks in the Polish Civil Court proceedings}

What we find in the substantial layer is that the legislator, in the Code of Civil Procedure, "is silent" about the articled clerk and - in the author's opinion - should also "be silent". The word 'articled clerk' does not appear in this Act. Corporate laws contain regulations regarding

4 Cf. A. Marciniak, in: W. Broniewicz, A. Marciniak, I. Kunicki, Postępowanie cywilne w zarysie, Warszawa 2016, pp. 201-207; A. Zieliński, in: Kodeks postepowania cywilnego. Komentarz, ed. A. Zieliński, Warszawa 2017, pp. 185-216; H. Ciepła, in: Kodeks postępowania cywilnego. Komentarz, vol. 1: Art. 1-366, eds. A. Marciniak, K. Piasecki, Warszawa 2016, pp. 412-460; H. Mądrzak, in: Postępowanie cywilne, ed. H. Mądrzak, Warszawa 2003, pp. 119-124; H. Pietrzkowski, Czynności procesowe zawodowego petnomocnika w sprawach cywilnych, Warszawa 2017, pp. 31-87; K. Wiszniewski, in: I. Wiszniewska, K. Wiśniewski, Petnomocnictwo procesowe..., pp. 9-10; M. Malczyk, in: Kodeks postępowania cywilnego, vol 1: Komentarz do art. 1-729, ed. A. Góra-Błaszczykowska, Warszawa 2016, pp. 370-403; M. Manowska, in: Kodeks postępowania cywilnego. Komentarz, vol. 1: Art. 1-50538, ed. M. Manowska Warszawa 2015, pp. 249-279; P. Osowy, Postępowanie cywilne w zarysie, Warszawa 2002, pp. 107-112; P. Telenga, in: Kodeks postepowania cywilnego. Komentarz, ed. A. Jakubecki, Warszawa 2015, pp. 145-159; S. Dalka, Sądowe postępowanie cywilne. Założenia ogólne i proces cywilny, vol. 1, Gdańsk 1992, pp. 115-122. 
to what extent and on what terms an articled clerk may be the proxy's representative. When assessing the position of an advocate articled clerk in civil proceedings, attention should be paid to the content of Article 77 s. 1 of the Act of 26 May 1982 - Advocates Law [AL]. ${ }^{5}$ Pursuant to this provision, following six months of legal training, an articled clerk may substitute the advocate before the courts, law enforcement agencies, state, local government and other institutions, except for the Supreme Court, the Supreme Administrative Court, the Constitutional Tribunal and the State Tribunal. Pursuant to Article 77 s. 4 of the $\mathrm{AL}$, these rights also apply to cases covered by the provision of legal aid ex officio. This is because the power of attorney ex officio corresponds to the substantial scope of the power of attorney resulting from Article 91 of the K.p.c., and thus includes the right of substitution and the right of advocate or legal adviser to appoint and be represented by an articled clerk. ${ }^{6}$ Additionally, it should be noted that, pursuant to Article $35^{1}$ s. 5 of the Act of 6 July 1982 on legal advisers, ${ }^{7}$ an advocate articled clerk may substitute a legal adviser on the same terms as an advocate, provided that the said legal adviser is a partner in an advocate-legal adviser partnership.

As follows from Article 77 Section 5 of the AL, as a rule, the advocate articled clerk is not only entitled to draw up pleadings (or rather - draft pleadings), but also to sign them. This rule is subject to several restrictions. First, the pleadings prepared by the trainee advocate must be - as is apparent from the literal wording of Article $77 \mathrm{Sec}-$ tion 5 of the AL - related to the appearance of the advocate in court. It is worth noting that such an advocate must act, within the proceedings, as a legal representative, appointed ex officio or by commission. Thus, for example - an advocate, who has been appointed a legal guardian for a defendant of unknown whereabouts, is not acting as a party's

5 The Act of 26 May 1982 - Advocate Law, (consolidated text: Journal of Laws of 2019, item 1513 as amended); hereinafter referred to as the AL.

6 Judgment of the SA in Warsaw of 30 July 2015, I ACa 1962/14, LEX no. 1843211. Cf. also the judgment of the Supreme Administrative Court [NSA] of 12 September 2012, I OSK 464/12, LEX no. 1264815.

7 Act of 6 July 1982 on legal advisers (consolidated text: Journal of Laws of 2018, item 2115, as amended); hereinafter referred to as the u.r.pr. Cf. I. Misiejuk, Czy aplikant na etacie zastapi obrońce??, Radca Prawny 2016, no. 1, pp. 28-29; idem, Czy aplikant pomoże przy bezpłatnych poradach?, Radca Prawny 2015, no. 4, pp. 44-45. 
representative in the said case. Therefore, he or she will not be entitled to authorize an articled clerk to substitute him or her. ${ }^{8}$ And thus an advocate's articled clerk is not entitled to draw up and sign pleadings related to the appearance of an advocate before the courts, provided that this advocate acts not as a legal representative, but as e.g. a guardian for a person with unknown place of residence, appointed on the basis of Article 144 of the Code of Civil Procedure, or as a guardian of a child remaining under parental authority, established by a guardianship court in accordance with Article 99 of the Act of 25 February 1964 Family and Guardianship Code. ${ }^{9}$

Secondly, the advocate's articled clerk must have the express authorization of the advocate, in which he is authorized to draw up and sign specific pleadings. In order for the authorization granted to the articled clerk to be process-effective, it is necessary to mention the type of document or documents that the clerk is authorized to sign. ${ }^{10}$ The provision of Article 77 Section 5 of the AL makes it clear that an advocate articled clerk cannot make and sign appeals, cassation appeals or constitutional complaints. As de lege ferenda a postulate we must indicate the need to extend the catalogs of procedural documents under Article 77 Section 5 of the AL and from Article $35^{1}$ Section 4 of the AL that may not be drawn up and signed by advocate's or legal adviser's articled clerks, with the new, extraordinary appeal, i.e. for an extraordinary complaint, generally regulated by provisions of Articles 89-95 of the Act of 8 December 2017 on the Supreme Court. ${ }^{11}$

8 Judgment of the SA in Katowice of 10 November 2010, V ACa 258/10, LEX no. 1131146.

9 Act of 25 February 1964 - Family and Guardianship Code, (consolidated text: Journal of Laws of 2019, item 2086).

10 Similar statement by Court of Appeal [SA] in Szczecin in the decision of 6 September 2016, for more information see the Decision of the SA in Szczecin of 6 September 2016, II AKz 384/16, LEX no. 2139160.

11 Act of 8 December 2017 on the Supreme Court (Journal of Laws of 2019, item 825). More on the extraordinary complaint, see A. Kotowski, Skarga nadzwyczajna na tle modeli kontroli odwotawczej, Prokuratura i Prawo 2018, no. 9, pp. 51-85; D. Gruszecka, Podstawy skargi nadzwyczajnej w sprawach karnych - uwagi w kontekście „wypetniania luk w systemie środków zaskarżenia", Palestra 2018, no. 9, pp. 27-40; M. Balcerzak, Skarga nadzwyczajna do Sądu Najwyższego w kontekście skargi do Europejskiego Trybunału Praw Człowieka, Palestra 2018, no. 1-2, pp. 11-22; T. Ereciński, K. Weitz, Skarga nadzwyczajna w sprawach cywilnych, Przegląd Sądowy 2019, no. 2, pp. 7-19; T. Zembrzuski, Wptyw wprowadzenia 
As it follows from Article 77 Section 2 of the LA, for a period of one year ${ }^{12}$ from the date of end of their clerk training, as indicated in the certificate of advocate apprenticeship completion, the advocate's articled clerk may substitute the advocate in the scope referred to in Section 1 of this provision. In its decision of 9 May 2018, the Supreme Court $^{13}$ indicates that pursuant to Article 77 Section 2 of the AL the advocate articled clerk, between taking the bar examination and being entered on the list of advocates, and taking the oath, was and still remains entitled to substitute the advocate in front of specific courts. Persons, who passed the bar examination in the period from the moment of adopting the resolution on the removal of an advocate's articled clerk from the list of clerks and entry on the list of advocates, and then advocates - from the moment of their final entry on the list of advocates to take an oath, and then - notification of the commencement of their professional activities, have the competence to appear in front of a court

skargi nadzwyczajnej na skargę o stwierdzenie niezgodności z prawem prawomocnego orzeczenia, Przegląd Sądowy 2019, no. 2, pp. 20-38. Cf. SN decision of 15 March 2019, IV CNP 30/18, LEX no. 2644659; SN decision of 7 March 2019, IV CNP 56/17, LEX no. 2640507; SN decision of 11 January 2019, II CNP 60/18, LEX no. 2634047; SN decision of 11 January 2019, II CNP 55/18, LEX no. 2620225; SN decision of 11 January 2019, II CNP 53/18 LEX no. 2620243; SN decision of 10 January 2019, II CNP 2/18, LEX no. 2634161; SN decision of 10 January 2019, II CNP 8/18, LEX no. 2611877; SN decision of 4 January 2019, IV CNP 27/18, LEX no. 2609897; SN decision of 27 December 2018, V CNP 38/18, LEX no. 2634025; SN decision of 27 December 2018, V CNP 35/18, LEX no. 2604674; SN decision of 27 December 2018, V CNP 31/18, LEX no. 2623956; SN decision of 6 November 2018, II CNP 46/18, LEX no. 2578434 or the SN decision of 31 October 2018, V CNP 18/18, LEX no. 2578439.

12 On 14 August 2019, the President of the Republic of Poland signed the Act of 19 July 2019 amending the Act - Advocate Law and the Act on Legal Advisers. This amendment enabled, in certain cases strictly specified in corporate laws and subject to the procedures specified in those laws, the articled clerk of advocate (respectively: legal adviser) to substitute the advocate (respectively: legal adviser) for a period of two years from the date of completion of the internship indicated in the certificate of completion of the advocate's internship (respectively: legal adviser's), see more generally: the Act of 19 July 2019 amending the Act - Advocate Law and the act on legal advisers, http://orka.sejm.gov.pl/proc8.nsf/ustawy/3027_u.htm, [retrieved on: 29.08.2019].

13 SN decision of 9 May 2018, IV KO 88/17, LEX no. 2499845. 
under substitution representation, however, these competences do not include the independent conduct of professional activities. ${ }^{14}$

Similar regulations apply to the position of legal adviser articled clerks and they are included in Article $35^{1}$ Section 1 and 2 u.r.pr. ${ }^{15}$ Meanwhile, in accordance with the provision of Article 9 Section 2 of the Act of 11 April 2001 on Patent Agents, ${ }^{16}$ a patent agent may grant further power of attorney (substitution) to another patent agent, as well, to the extent specified in Article 36 Section 1 of the Patent Agents Act - to his or her articled clerk. Pursuant to Article 36 Section 1 of this Act, eighteen months after the start of the training, the patent agent managing the internship (patron) may authorize his articled clerk to substitute him in all activities.

Finally, it is worth paying attention to the type of document on the basis of which the articled clerk (advocate or legal adviser) is allowed to participate in civil proceedings. The advocate's articled clerk - as opposed to the substitution attorney who acts in civil proceedings on the basis of a substitute power of attorney - is entitled to substitute a lawyer under the condition of submission of the appropriate authorization. In the case of substitution (further power of attorney) granted by an advocate to another advocate or legal adviser, there is an obligation to pay stamp duty subject to the principles set out in the Stamp Duty Act. ${ }^{17}$ On the other hand, the obligation to pay this public levy does not arise in the case of an advocate's articled clerk being authorized to substitute the advocate pursuant to Article 77 of the LA, as it does not constitute a power of

14 Opinion of the Supreme Bar Council on legal representation after the bar exam, E-informator KrakowskiejIzby Adwokackiej2017, no.4,https:/ /adwokatura.krakow.pl/ e-informator-krakowskiej-izby-adwokackiej/e-informator-kia-nr-42017/opinia-nra -ws-zastepstwa-procesowego-po-egzaminie-adwokackim-1222.html, [retrieved on: 4.04.2018]. Cf. T. Sobel, Opinia o możliwości zastępstwa radcy prawnego przed sądami i innymi organami przez aplikantów, którzy otrzymali zaświadczenia o ukończeniu aplikacji, Radca Prawny 2013, no. 2, pp. 19-21.

15 Cf. M. Smyk, Status prawny aplikanta radcowskiego w postępowaniu cywilnym (głos w dyskusji), Przegląd Sądowy 2010, no. 2, pp. 124-139; P. Olszewski, Wolność stowa aplikanta, Radca Prawny 2016, no. 6, pp. 2-3.

16 The Act of 11 April 2001 on Patent Agents, (consolidated text: Journal of Laws of 2019, item 1861).

17 Act of 16 November 2006 on stamp duty, (consolidated text: Journal of Laws of 2019, item 1000, as amended). 
attorney within the meaning of the Act on stamp duty, as well as the Code of Civil Procedure. ${ }^{18}$

\section{Articled clerk as an alter ego of the advocate}

It is clear, from the aforesaid regulations, that the articled clerk replaces the advocate, legal adviser or patent agent, respectively, and not the party to the proceedings, which is worth emphasizing at this point. ${ }^{19}$ Pursuant to Article 77 of the AL the advocate articled clerk may substitute the advocate in front of the courts and, as a consequence, take actions "such as" the legal representative of a party, and not - as a the legal representative of a party. ${ }^{20}$ There is no unified position in the doctrine regarding the position of the articled clerk in the proceedings. Some consider the articled clerk to be the legal representative of advocate. Others support the position that he or she is simply a procedural substitute. ${ }^{21}$ What is sufficient for our further analysis is to limit ourselves to the thesis that the advocate's articled clerk neither acts on his own behalf nor represents his private interests, and the decision to be taken in the case will not directly concern his legal sphere. An articled clerk, replacing an entity that

18 Judgment of the Provincial Administrative Court [WSA] in Gliwice of 2 April 2008, ISA/G1 37/08, LEX no. 422225.

19 Z. Klatka, Ustawa o radcach prawnych. Komentarz, Warszawa 1999, pp. 291-294; E. Tkaczyk, Ustawa o rzecznikach patentowych. Komentarz, Warszawa 2012, pp. 169-170; J. Trela, in: Prawo o adwokaturze. Komentarz, ed. P. Kruszyński, Warszawa 2016, pp. 177-179.

20 Similarly, the Supreme Court in its judgment of 8 December 2011, cf. judgment of the SN of 8 December 2011, IV CSK 172/11, LEX no. 1119547.

${ }^{21}$ An analysis of positions regarding the trial position of an articled clerk is interestingly presented by G. Borkowski, cf. G. Borkowski, Aplikant adwokacki w postępowaniu cywilnym - substytut czy zastępca adwokata?, Palestra 2009, no. 11-12, pp. 101-112. Cf. also idem, Glosa to the SN resolution of 28 June 2006. III CZP 27/06, Przegląd Sądowy 2008, no. 6, pp. 140-151. In addition, it is worth paying attention to the position expressed by G. Matusik and M. Śladkowski regarding articled clerk advocate, cf. G. Matusik, M. Śladkowski, Pozycja prawna aplikanta radcowskiego w postępowaniu cywilnym, Przegląd Sądowy 2008, no. 11-12, pp. 91-105. 
is not a third party in a civil trial, cannot and does not constitute a third party himself. ${ }^{22}$

A look from a slightly different perspective, on the status of an advocate's articled clerk in the Polish civil trial, may lead to an interesting conclusion. What seems particularly interesting is the view expressed by Kazimierz Lipiński, who in relation to the advocate's articled clerk indicates that his procedural activities have a direct effect on the plaintiff or defendant only because they are carried out on behalf of the advocate, who is the party's attorney. In his opinion, the advocate's articled clerk is merely an alter ego of the said lawyer. ${ }^{23}$ This position still holds its validity and accuracy today. Being - only or as much as - an alter ego of an advocate very vividly reflects the essence and sense of "articled clerk's existence" in a civil trial.

The Supreme Court made an interesting statement about articled clerks in its 28 June 2006 resolution. ${ }^{24}$ In its opinion, the articled clerk as a substitute does not obtain the status of legal representative, because he acts only for him (on his behalf) and never comes to replace him. The substitute represents the advocate, who authorized him and, although his actions have an effect on the party, it is not because he is his legal representative, but because he acts on behalf of the latter. The Supreme Court pointed out that there is no legal bond between the party and

${ }^{22}$ For more on a third party and another person in a civil trial, cf. K. Dróżdż, Osoby trzecie jako współczynnik efektywnej ochrony sądowej w cywilnym postępowaniu procesowym, Zeszyty Naukowe KUL 2017, no. 3, pp. 43-59; eadem, Osoba trzecia jako podmiot uprawniony do wniesienia skargi na czynności komornika, in: Środki zaskarżenia w sadowym postępowaniu egzekucyjnym. Zbiór studiów, ed. J. Misztal-Konecka, Sopot 2017, pp. 73-82; eadem, Inna osoba jako podmiot legitymowany do złożenia skargi na czynności komornika, in: Cecha sprawiedliwości jest nie krzywdzić ludzi. Księga pamiątkowa ku czci Zenona Knypla, ed. Z. Szczurek, G. Sikorski, Sopot 2017, pp. 13-20; eadem, Matżonek dtużnika jako osoba trzecia legitymowana do wytoczenia powództwa o zwolnienie zajętego przedmiotu od egzekucji sądowej, Przegląd Prawa Egzekucyjnego 2016, no. 5, pp. 49-61.

${ }^{23}$ K. Lipiński, Czy aplikant adwokacki, upoważniony przez adwokata do zastapienia go, może być przez sąd dopuszczony tymczasowo do udziatu w rozprawie, gdy nie może na razie przedstawić petnomocnictwa dla adwokata, który udzielit aplikantowi upoważnienia (art. 89 § 1 k.p.c.)?, Palestra 1959, no. 7-8, pp. 110-111. Cf. A. Marciniak, Upoważnienie aplikanta komorniczego do samodzielnego wykonywania określonych czynności egzekucyjnych, Przegląd Sądowy 2015, no. 9, pp. 92-99 and J. Studzińska, Uprawnienia aplikanta komorniczego - problemy praktyczne, Przegląd Prawa Egzekucyjnego 2016, no. 1, pp. 87-109.

24 SN Resolution of 28 June 2006, III CZP 27/06, Legalis no. 74976. 
the substitute advocate, which usually precedes the granting of a power of attorney, and therefore the substitute generally does not bear any liability towards the party. He bears it exclusively towards his principal. In addition, in the resolution cited above, the Supreme Court pointed out that the substitution entrusted to the articled clerk, usually by the patron, is a purely corporate institution, aiming primarily at educational functions consisting in training and professional development. In some cases, it is probably also about providing "organizational facilities" for the advocate's work.

The legal position of an advocate's articled clerk should be assessed through the prism of what is the function or the essence of the advocate's apprenticeship, which is aimed at proper preparation for the profession of advocate. Legal representation is one of the most important elements of proper preparation for the exercise of this profession, allowing participants to acquire adequate procedural experience, as well as to get used to the specifics and dynamics of civil proceedings, which cannot be rendered even by the best simulations of trials. ${ }^{25}$ When the advocate's articled clerk attains the required minimum preparation for the proper performance of legal representation (and it seems - as follows from the literal wording of Article 77 Section 1 of the AL - he has six months from starting his advocate's apprenticeship, if he has not previously practiced in an office), he is able to substitute the advocate (and a legal adviser in a case specified by law) bin front of a court - while standing before the judicial authority not yet dressed in a gown, nor with his own customer. Here comes the moment, which this articled clerk is probably looking forward to.

\section{Some restrictions on the rights of the person preparing to perform the profession of an advocate in selected legal systems}

A moment comes, when the articled clerk may replace the advocate, be his alter ego. However, since he is not an advocate, but a person duly preparing for the exercise of this profession of public trust, it is natural

25 Similarly M. Lewandowski, Egzaminowany aplikant adwokacki - zagadnienia instytucjonalno-procesowe, Edukacja Prawnicza 2013, no. 1, p. 22. 
and obvious that the scope of his powers must be limited. In the Polish legal system, this limitation does not directly consist of isolating a specific category of cases in which an advocate's articled clerk cannot appear before a court as a legal representative of the advocate. There is also no provision under which an advocate's articled clerk could only appear before the courts of first instance before which, as a rule, only minor cases are considered. Pursuant to Article 77 Section 1 of the AL, an advocate's articled clerk cannot only substitute for the advocate appearing in front of the Supreme Court, the Supreme Administrative Court, the Constitutional Tribunal and the State Tribunal. Another limitation is the extraction of a catalog of procedural documents that the articled clerk cannot effectively sign - even if he has the appropriate authorization from the advocate. ${ }^{26}$ Pursuant to Article 77 Section 5 of the AL these documents are appeal, cassation appeal and the constitutional complaint.

This is different in the German legal system, in which a person who is an intern at the office within a position (Stationsreferendar), ${ }^{27}$ assigned to a specific lawyer in accordance with $\S 59 \mathrm{BRAO},{ }^{28}$ has strictly defined powers to perform legal representation - unlike persons practicing at the office in as a secondary activity (in Nebentätigkeit). The latter are deprived of the right to represent, so in the event of their substitution, the court adjudicating in the case will apply $\S 79$ para. $3 \mathrm{ZPO} .{ }^{29}$ In turn, the trainee advocate has a limited scope of powers in the sense that he cannot substitute for a lawyer before just any court. In principle, he may perform procedural actions as a substitute before the court of first instance, which is the district court (Amtsgericht, AG), in accordance with $\S 79 \mathrm{ZPO}^{30}$ and $\S 157 \mathrm{ZPO}^{31}$ In turn, according to $\S 78 \mathrm{ZPO}$, in

26 Cf. SN decision of 26 May 2017, I CZ 60/17, LEX no. 2309607.

${ }_{27}$ Hereinafter referred to as the trainee or Stationsreferendar, in order to clearly separate the institutions of the German trainee or Stationsreferendar from the Polish advocate's articled clerk.

28 Die Bundesrechtsanwaltsordnung vom 1. August 1959 (regulations of the Federal Bar), https:/ / www.gesetze-im-internet.de/brao/_ 59.html [retrieved on: 18.04.2019].

29 Die Zivilprozessordnung vom 30. Januar 1877 (German Code of Civil Procedure), https://www.gesetze-im-internet.de/zpo/ZPO.pdf [retrieved on: 18.04.2019].

30 Cf. M. Vollkommer, in: Zivilprozessordnung. Kommentar, ed. R. Zöller, Köln 2010, pp. 324-336, 339-343, 662. See also L. Rosenberg, K. Schwab, P. Gottwald, Zivilprozessrecht, Mündchen 2010.

31 Cf. R. Greger, in: Zivilprozessordnung..., pp. 662. 
proceedings pending before regional courts (Landgerichten - LG, which may be courts of both first and second instance) and before national courts of appeal (Oberlandesgerichten - OLG, acting as courts of second instance), the German procedure introduces the obligation of advocate representation (Anwaltszwang). In proceedings in front of LG and OLG, substitution by a trainee is in principle excluded in so far as he has not obtained the right to act as representative (Allgemein Vertreter) during e.g. advocate's absence from the office for more than a week ( $\$ 53 \mathrm{BRAO})$. Pursuant to $\S 53$ Section $4 \mathrm{BRAO}$, a trainee may be appointed to perform this function if he or she has completed at least twelve months of internship (Vorbereitungsdienst). Pursuant to § 173 Section 1 BRAO, trainees cannot substitute for an advocate in front of the Federal Court of Justice (Bundesgerichtshof-BGH). Considering the above, it is not too far-reaching to say that the Polish advocate's articled clerk has, in practice, more opportunities to acquire adequate trial skills. It seems that the most important benefit resulting from the lack of regulations similar to $\S 78 \mathrm{ZPO}$ and $\S 53 \mathrm{BRAO}$ in the Polish legal system is, above all, ensuring that Polish articled clerks have greater opportunity to appear in front of the courts of second instance. The specifics of conducting cases before higher courts are different. For this reason, people who apply for advocate's qualifications should certainly be able to "get used to" participating in the conduct of cases not only before the courts proceedings pending at first instance.

The German system of law lacks the equivalent of the Polish provisions of Article 77 Section 5 LA and Article $35^{1}$ Section 5 LA, listing the catalog of procedural documents, which cannot be signed by a Polish advocate's or legal adviser's articled clerks. The author also met with the opinion stating that it is rather not practiced in Germany to sign pleadings by trainees, however she did not find a provision that would imply that such an act would not be legally ineffective insofar as it would comply with e.g. $\S 78 \mathrm{ZPO}$ and $\S 79 \mathrm{ZPO}$.

As a side note, it is worth pointing out that on the language level there is also no distinction between the document on the basis of which the trainee and another advocate act under legal representation before the court. These documents are called powers of attorney (Untervollmacht - this is not the main power of attorney, because the latter is referred to as Vollmacht). Meanwhile, in the Polish legal system it is characteristic to distinguish a document based on which an advocate's articled 
clerk operates (this document is called an authorization) from a document, based on which another advocate operates, referred to as a further representative, substitute proxy or substitute (this document is referred to as further proxy or a substitute power of attorney).

When we turn our attention to the Italian system of law now, we see that pursuant to Article 41 Section 12 of the Law - New regulation of the legal professions (Nuova disciplina dell'ordinamento della professione forense), ${ }^{32}$ a lawyer apprentice of an advocate (praticante avvocato) ${ }^{33}$ may substitute his patron in civil matters falling within the competence of the justice of the peace (un giudice di pace ${ }^{34}$ ) and a court (ordinary - tribunale $\left.e^{35}\right)$. A contrario, he cannot act as an alter ego of the advocate in front of special and higher courts. Considering the aforesaid, we must observe that the person in question cannot replace the advocate in front of a juvenile court, constitutional court, court of appeal or cassation. ${ }^{36}$ As a side note, it should be noted that while the advocate's apprenticeship lasts three years in Poland, the apprenticeships in the office in Italy only lasts one and a half years (although in extreme cases they can last five years), which results from Article 41, Section 12 of Act No. 247/2012. Given the significant difference in the duration of the apprenticeship in Poland or the practice in the office in Italy, respectively, it should not be surprising to find such significant differences in the regulation of the rights of an Italian apprentice in the matter of performing legal representation in court compared to a Polish articled clerk.

32 Legge 31 dicembre 2012, n. 2471 Nuova disciplina dell'ordinamento della professione forense (New regulation of legal professions), https://www.consiglionazionaleforense.it/documents /20182/0/Legge+247-2012+-+Testo+aggiornato+al+5+giugno+2018/ c8146804-2291-4c3e-b49f-f1c41a53bec0?fbclid=IwAR2SGFMGcGtvmGu8_yqyGRCcCn2qer9S7scL9q5VoTeY6QnvPBQrMR9RFyI, [retrieved on: 25.04.2019]; hereinafter: Act no. $247 / 2012$.

${ }^{33}$ Hereinafter referred to as the apprentice, in order to clearly separate the institutions of the Italian apprentice from the Polish advocate's articled clerk.

${ }^{34}$ For the competences of justice of peace, see, e.g. the art. 7 Regio decreto 28 ottobre 1940, n. 1443. Codice di procedura civile (Italian Code of Civil Procedure), https:/ / www .brocardi.it/codice-di-procedura-civile/libro-primo/titolo-i/capo-i/sezione-ii/art7.html?fbclid=IwAR1pjqMgLqKwl1DGrrccrzMMfQs51KnSdaaE8QvWYYy0Vc4IIa2Or75RM6M, [retrieved on: 25.04.2019], hereinafter: CPC.

35 Cf., e.g., Article a CPC.

36 For more on the Italian judicial system, see https://e-justice.europa.eu/content_ judicial_systems_in_member_states-16-it-pl.do?member=1 [retrieved on: 25.04.2019]. 
The provision of Article 41Section 12 of Act No. 247/2012 means that there are several other restrictions on the scope of rights of a person preparing to practice the profession of advocate in Italy. Similarly to Poland, a trainee during legal internship, if he has legal education, can perform professional activities substituting the advocate, only after six months from registering in the register of practitioners (from that moment the intern is referred to as praticante abilitato). Thus, the Italian legislator - just like the Polish - introduced a six-month period during which the apprentice has time to attain minimum preparation for proper performance of legal representation.

What's more, from the literal wording of Article 41 Section 12 of Act No. 247/2012 follows that the apprentice may replace only the advocate that is responsible for his apprenticeship. The document forming the basis for their court actions is referred to as delega a sostituto (in turn the main power of attorney is referred to as procura alle liti). As in Germany, the same applies to the document that the apprentice and other advocate receive by virtue of which they substitute the principal representative in the case. In turn, according to Article 42 Section 1 of Act No. 247/2012, the apprentice is obliged to observe the same deontological principles as an advocate. ${ }^{37}$

Within the Ukrainian legal system, however, there is the institution of an advocate's assistant (Помічник адвоката), ${ }^{38}$ which has only few similarities to the Polish institution of the advocate's articled clerk. Relations between the Ukrainian assistant advocate ${ }^{39}$ on the one hand and the advocate, advocate's office or the association of advocates on the other are based on an employment relationship in accordance with Article 16 Section 1 of Act No. 5076-V. It should be noted that the assistant performs the work

37 Cf. Codice Deontologico Forense, modificato nella seduta amministrativa del 23 febbraio 2018 e pubblicato sulla Gazzetta Ufficiale n. 86 del 13 aprile 2018, in vigore dal12 giugno 2018 (Italianjudicial code of ethics), https:/ / www.consiglionazionaleforense.it/ documents / 20182/40227/Codice+Deontologico+Forense+\%28aggiornato+al+2016\%29/18465b6e-0218-44d2-92b5-92291e1c1ea4?fbclid=IwAR3ZPycIX-nTVSFT1z3xOh7Fj4 vMlh4VF-ONag9yUzkWMw9oPQxjyrtETMg [retrieved on: 5.04.2019].

$38 \mathrm{Cf}$. art. 16 of the act Про адвокатуру та адвокатську діяльність of 05 July 2012 no. 5076-V (Ukrainian act on bar and profession of advocate of 5 July 2012), https://zakon2.rada.gov.ua/laws/show/5076-17/paran3\#n3 [retrieved on: 30.07.2019]; hereinafter: Act no. 5076-V.

39 Hereinafter referred to as an assistant, in order to clearly separate the institutions of the Ukrainian advocate's assistant from the Polish advocate's articled clerk. 
entrusted to him by the advocate in the context of his cases, excluding those tasks that fall within the advocate's procedural competences (Article 16 Section 2 of Act No. 5076-V). The Act does not introduce a training obligation in the shape of a Polish bar clerkship. After two years of work, a lawyer's assistant may take the bar examination, and if he passes it successfully, he is released from the obligation to complete a six-month advocate's internship. Although the subject of the present study is not the form of practicing the profession after passing the professional examination, however, one should notice the rather interesting legal solution, which is the institution of an advocate's internship. Namely, a person who has passed the bar examination must still undergo an internship with an advocate according to the referral from a regional bar council, insofar as he/ she had not previously served as an advocate's assistant. Pursuant to Article 10 of Act No. 5076-V, the purpose of the internship is simply to verify that the candidate is properly prepared for independent work. ${ }^{40}$ As a side note, it should also be mentioned that according to Article 60 Section 2 of the Code of Civil Procedure of Ukraine, ${ }^{41}$ such an assistant advocate, like any other person over the age of eighteen - may act as a representative of a party in dealing with disputes arising from employment relationships, as well as matters related to minor disputes (minor cases).

Summing up the above considerations, it should be pointed out that the thesis stating that the Polish articled clerks enjoy relatively high trust of the Polish legislator, is not too far-reaching, in the sense that they have the opportunity to perform a substitution in a broader scope than German trainees, Italian apprentices or Ukrainian assistants. The model of Polish advocate clerkship combined with the practice of the patron gives the possibility of real, reliable and proper preparation for the profession of advocate, provided the articled clerk will make proper use of this period in his professional life.

40 Cf. A. Kosyło, Nowa ustawa o adwokaturze na Ukrainie, Palestra 2013, nr 1-2, pp. 162-167 and idem, Pomoc prawna w demokratycznym państwie prawnym: regulacje unijne, polskie oraz ukraińskie, in: Ius et amicitia. Materiały Pierwszego Polsko-Ukraińskiego Forum Prawniczego, Tarnobrzeg 2006, p. 178.

41 Цивільний процесуальний кодекс України of 18 March 2003 (Ukrainian Code of Civil Procedure), https://zakon.rada.gov.ua/laws/show/1618-15?fbclid=IwAR3b9VS D6lgW30JOFYLdmKsRHTq1cLAZXqXDMymqVKQTETImqioIndWeiLA [retrieved on: 9.08.2019]. 


\section{Conclusion}

After the amendment to Article 77 of the Act - Advocate Law, pursuant to which the fifth section was added, according to which the articled clerk may draw up and sign pleadings related to the appearance of the advocate in front of courts, law enforcement authorities and state, local government and other institutions - with the express authorization of the advocate, excluding appeals, cassation appeals and constitutional complaints, there were views criticizing the said amendment. At that time, it was argued that it is not rational to introduce the requirement of explicit authorization of the clerk to sign pleadings. This position was justified by the fact that the same articled clerk, who would not be authorized to sign the pleading and thus, e.g. would not be entitled to withdraw the action, may then effectively withdraw the action at the hearing, in the absence of the advocate. All he needs for this end is a "normal" authorization. This view cannot be accepted, first and foremost, because it dangerously equates the articled clerk, who has been authorized to sign a specific pleading with the articled clerk who has been authorized to act in court proceedings.

The articled clerk is the alter ego of the advocate in this particular case, and before that particular court. Finally, there he is also the "here and now" alter ego of the said advocate. Moreover, this "alter egocity" is particularly updated in the courtroom, and not in the privacy of the office. For this reason, an articled clerk, who has not been authorized in writing by his patron or other advocate to sign a pleading in which, for example, he withdraws the action in its entirety, may effectively perform this procedural act before the court, acting on the basis of the authorization, entitling him to substitute the lawyer in the respective proceedings. An articled clerk, who receives authorization to act in a particular case before a court obtains rights almost equal to those of an advocate. The authorization granted to a clerk by an advocate is linked with granting him a credit trust that he will be able to properly substitute for the advocate, by being his alter ego. For this reason, comparing the status of an articled clerk, who has been authorized to sign a specific pleading, with the status of an articled clerk, who has been authorized to act in front of a court throughout the procedure is unfounded and harmful to the latter person. 


\section{Bibliography}

Balcerzak M., Skarga nadzwyczajna do Sądu Najwyższego w kontekście skargi do Europejskiego Trybunału Praw Człowieka, Palestra 2018, no. 1-2.

Borkowski G., Glosa do uchwaty SN z 28.06.2006 r. III CZP 27/06, Przegląd Sądowy 2008, no. 6 .

Borkowski G., Aplikant adwokacki w postępowaniu cywilnym - substytut czy zastępca adwokata?, Palestra 2009, no. 11-12.

Broniewicz W., Marciniak A., Kunicki I., Postępowanie cywilne w zarysie, Warszawa 2016.

Dalka S., Sądowe postępowanie cywilne. Założenia ogólne i proces cywilny, vol. 1, Gdańsk 1992.

Dróżdż K., Inna osoba jako podmiot legitymowany do złożenia skargi na czynności komornika, in: Cecha sprawiedliwości jest nie krzywdzić ludzi. Księga pamiątkowa ku czci Zenona Knypla, ed. Z. Szczurek, G. Sikorski, Sopot 2017.

Dróżdż K., Małżonek dłużnika jako osoba trzecia legitymowana do wytoczenia powództwa o zwolnienie zajętego przedmiotu od egzekucji sądowej, Przegląd Prawa Egzekucyjnego 2016, no. 5.

Dróżdż K., Osoba trzecia jako podmiot uprawniony do wniesienia skargi na czynności komornika, in: Środki zaskarżenia w sądowym postępowaniu egzekucyjnym. Zbiór studiów, ed. J. Misztal-Konecka, Sopot 2017.

Dróżdż K., Osoby trzecie jako współczynnik efektywnej ochrony sądowej w cywilnym postepowaniu procesowym, Zeszyty Naukowe KUL 2017, no. 3.

Ereciński T., Weitz K., Skarga nadzwyczajna w sprawach cywilnych, Przegląd Sądowy 2019, no. 2.

Gruszecka D., Podstawy skargi nadzwyczajnej w sprawach karnych - uwagi w kontekście „wypetniania luk w systemie środków zaskarżenia”, Palestra 2018, no. 9.

Kaczyński M., Petnomocnik z urzędu w sądowym postępowaniu cywilnym, Warszawa 2014.

Klatka Z., Ustawa o radcach prawnych. Komentarz, Warszawa 1999.

Kodeks postepowania cywilnego, vol. 1: Komentarz do art. 1-729, ed. A. Góra-Błaszczykowska, Warszawa 2016.

Kodeks postępowania cywilnego. Komentarz, ed. A. Jakubecki, Warszawa 2015.

Kodeks postepowania cywilnego. Komentarz, vol. 1: Art. 1-366, ed. A. Marciniak, K. Piasecki, Warszawa 2016.

Kodeks postępowania cywilnego. Komentarz, ed. A. Zieliński, Warszawa 2017.

Kodeks postepowania cywilnego. Komentarz, vol. 1: Art. 1-50538, ed. M. Manowska, Warszawa 2015.

Kosyło A., Nowa ustawa o adwokaturze na Ukrainie, Palestra 2013, no. 1-2. 
Kosyło A., Pomoc prawna w demokratycznym państwie prawnym: regulacje unijne, polskie oraz ukraińskie, in: Ius et amicitia. Materiaty Pierwszego Polsko-Ukraińskiego Forum Prawniczego, Tarnobrzeg 2006.

Kotowski A., Skarga nadzwyczajna na tle modeli kontroli odwoławczej, Prokuratura i Prawo 2018, no. 9.

Lewandowski M., Egzaminowany aplikant adwokacki - zagadnienia instytucjonalno-procesowe, Edukacja Prawnicza 2013, no. 1.

Lipiński K., Czy aplikant adwokacki, upoważniony przez adwokata do zastapienia go, może być przez sąd dopuszczony tymczasowo do udziału w rozprawie, gdy nie może na razie przedstawić petnomocnictwa dla adwokata, który udzielit aplikantowi upoważnienia (art. 89 § 1 k.p.c.)?, Palestra 1959, no. 7-8.

Marciniak A., Upoważnienie aplikanta komorniczego do samodzielnego wykonywania określonych czynności egzekucyjnych, Przegląd Sądowy 2015, no. 9.

Matusik G., Śladkowski M., Pozycja prawna aplikanta radcowskiego w postępowaniu cywilnym, Przegląd Sądowy 2008, no. 11-12.

Misiejuk I., Czy aplikant na etacie zastapi obrońcę?, Radca Prawny 2016, no. 1.

Misiejuk I., Czy aplikant pomoże przy bezpłatnych poradach, Radca Prawny 2015, no 4.

Olszewski P., Wolność słowa aplikanta, Radca Prawny 2016, no. 6.

Osowy P., Postępowanie cywilne w zarysie, Warszawa 2002.

Pietrzkowski H., Czynności procesowe zawodowego petnomocnika w sprawach cywilnych, Warszawa 2017.

Postępowanie cywilne, ed. H. Mądrzak, Warszawa 2003.

Prawo o adwokaturze. Komentarz, ed. P. Kruszyński, Warszawa 2016.

Rosenberg L., Schwab K., Gottwald P., Zivilprozessrecht, Mündchen 2010.

Smyk M., Status prawny aplikanta radcowskiego w postepowaniu cywilnym (głos w dyskusji), Przegląd Sądowy 2010, no. 2.

Sobel T., Opinia o możliwości zastępstwa radcy prawnego przed sądami i innymi organami przez aplikantów, którzy otrzymali zaświadczenia o ukończeniu aplikacji, Radca Prawny 2013, no. 2.

Studzińska J., Uprawnienia aplikanta komorniczego - problemy praktyczne, Przegląd Prawa Egzekucyjnego 2016, no. 1.

Tkaczyk E., Ustawa o rzecznikach patentowych. Komentarz, Warszawa 2012.

Wiszniewska I., Wiszniewski K., Petnomocnictwo procesowe w sprawach cywilnych. Komentarz praktyczny z orzecznictwem, Warszawa 2014.

Zembrzuski T., Wpływ wprowadzenia skargi nadzwyczajnej na skargę o stwierdzenie niezgodności z prawem prawomocnego orzeczenia, Przegląd Sądowy 2019, no. 2.

Zivilprozessordnung. Kommentar, ed. R. Zöller, Köln 2010. 


\section{Sum mary}

The article presents a view concerning the status of the advocate's articled clerk in the Polish civil court proceedings. At the same time, it should be emphasized that the purpose of the present study was not to answer the question, whether this subject is a representative or substitute within the proceedings, but rather to present a slightly different opinion on the role of articled clerk in civil procedure, taking the special function of the advocate pupillage into account. This study seems to be interesting, for example as it somehow "touches" the sensitive point of interconnection between civil procedural law and internal regulations of the Bar. Although the analysis is aimed at defining the status of an articled clerk in the Polish civil court proceedings, the inclusion of references to regulations regarding the position of legal adviser's articled clerk serves us to broaden the scope of evaluation and make the study more attractive. Furthermore, simple proof of validity of the presented thesis, according to which the advocate's articled clerk acts as an alter ego of the advocate, would not be that interesting, without referring to the German, Italian and Ukrainian legal systems. The comparison of these four legal orders, i.e. the Polish, German, Italian and Ukrainian ones, led us to an interesting conclusion. Namely, an articled clerk has the opportunity to perform legal representation in a wider scope than the German trainee, Italian apprentice or Ukrainian assistant advocate. Consequently, his or her role as a trial deputy is special. It is the scope of the rights of the Polish articled clerk that grants him or her the basis act as an alter ego of the advocate.

Key words: advocate's internship, advocate's articled clerk, advocate, authorization and power of attorney, deputy, representation, Stationsreferendar, praticante avvocato, Помічник адвоката

\section{STATUS PRAWNY APLIKANTA ADWOKACKIEGO W POLSKIM PROCESIE CYWILNYM - UWAGI NA TLE PRAWNOPORÓWNAWCZYM}

\section{Streszczenie}

W artykule został zaprezentowany pogląd dotyczący statusu aplikanta adwokackiego w polskim procesie cywilnym. Równocześnie należy podkreślić, że celem niniejszego opracowania nie było uzyskanie odpowiedzi na pytanie, czy podmiot ten zajmuje $\mathrm{w}$ postępowaniu pozycję zastępcy procesowego albo substytuta, a przedstawienie nieco odmiennej opinii na temat roli aplikanta adwokackiego w postępowaniu cywilnym z uwzględnieniem szczególnej funkcji, którą spełnia aplikacja adwokacka. Niniejsze studium wydaje się być interesujące chociażby z tego względu, że niejako "dotyka” ono newralgicznego punktu styku prawa 
cywilnego procesowego i regulacji wewnątrzkorporacyjnych. Chociaż przeprowadzona analiza ma na celu określenie statusu aplikanta adwokackiego w polskim procesie cywilnym, zawarcie w pracy odwołań do regulacji dotyczących pozycji aplikantów radcowskich czy rzeczniowskich służyło poszerzeniu spektrum oceny i uatrakcyjnieniu opracowania. $Z$ kolei dowodzenie słuszności prezentowanej tezy, zgodnie z którą aplikant adwokacki pełni rolę alter ego adwokata, nie byłoby aż tak interesujące bez odwołania się do systemu prawa niemieckiego, włoskiego i ukraińskiego. Porównanie tych czterech porządków prawnych, tj. polskiego, niemieckiego, włoskiego i ukraińskiego, doprowadziło do ciekawej konkluzji. Mianowicie aplikant adwokacki ma zapewnioną możliwość wykonywania zastępstwa procesowego w szerszym zakresie niż niemiecki stażysta, włoski praktykant czy ukraiński pomocnik. Co za tym idzie, jego rola jako zastępcy procesowego jest szczególna. To właśnie zakres uprawnień polskiego aplikanta adwokackiego daje mu podstawę do określania siebie jako alter ego adwokata.

Słowa kluczowe: aplikacja adwokacka, aplikant adwokacki, adwokat, upoważnienie a pełnomocnictwo, zastępstwo, przedstawicielstwo, Stationsreferendar, praticante avvocato, Помічник адвоката

\section{ПРАВОВОЙ СТАТУС АДВОКАТА-СТАЖЕРА В ПОЛЬСКОМ ГРАЖДАНСКОМ СУДОПРОИЗВОДСТВЕ - КОММЕНТАРИИ ПО СРАВНИТЕЛЬНОМУ ПРАВУ}

\section{Резюме}

В статье представлен взгляд на статус стажера адвоката в гражданском судопроизводстве в Польше. В то же время, следует подчеркнуть, что цель данного исследования заключалась не в том, чтобы ответить на вопрос, является ли данный субъект законным представителем или его заместителем в судебном разбирательстве, а в том, чтобы представить несколько иное мнение о роли стажера адвоката в судебном разбирательстве по гражданским делам с учетом конкретной функции подготовки адвокатов. Настоящее исследование представляется интересным хотя бы потому, что оно «затрагивает» чувствительную точку соприкосновения Гражданского процессуального права и внутрикорпоративного регулирования. Хотя проведенный анализ направлен на определение статуса стажера адвоката в польском гражданском процессе, включение в работу ссылок на положения о должности стажера юридического советника или стажера патентного поверенного способствовало расширению спектра оценки и увеличению разносторонности настоящего исследования. С другой стороны, доказывать справедливость представленного тезиса, согласно которому стажер-адвокат играет роль 
alter ego адвоката, было бы не так интересно без ссылки на правовую систему Германии, Италии и Украины. Сравнение этих четырех правовых порядков - польского, немецкого, итальянского и украинского - привело к интересному выводу. А именно, стажер адвоката имеет возможность выполнять юридическое представительство в большей степени, чем немецкий стажер, итальянский стажер или украинский помощник. Следовательно, его роль как уполномоченного является особенной. Именно объем прав польского адвоката-стажера дает ему основание определять себя как alter ego адвоката.

Ключевые слова: стажировка в адвокатуре, адвокат-стажер, стажер юридического советника, полномочия и доверенность, судебное представительство, законное представительство, Stationsreferendar, praticante avvocato, Помічник адвоката 